\title{
An Independent Validation of 2010 Tumor-Node-Metastasis Classification for Renal Cell Carcinoma: A Multi-center Study by the Urooncology Association of Turkey Renal Cancer-Study Group
}

\author{
Böbrek Hücreli Kanser Tümör-Nod-Metastaz 2010 Sinıflaması Türkiye Validasyonu: \\ Üroonkoloji Derneği Böbrek Kanseri Çalışma Grubu Çok Merkezli Çalışması
}

Tayyar Alp Özkan', Saadettin Eskiçorapçı², Özgür Yaycıoğlu³, Bülent Akdoğan ${ }^{4}$, Çağatay Göğüs ${ }^{5}$, Ayhan Dirim ${ }^{6}$, Cavit Can ${ }^{7}$, Asıf Yıldırım ${ }^{8}$, Haluk Özen ${ }^{4}$, Levent Türkeri' ${ }^{9}$, Urooncology Association of Turkey Renal Cancer-Study Group

'University of Health Sciences, Kocaeli Derince Training and Research Hospital, Clinic of Urology, Kocaeli, Turkiye

${ }^{2}$ Acıbadem University Faculty of Medicine, Department of Urology, Istanbul, Turkiye

${ }^{3}$ Başkent University Faculty of Medicine, Department of Urology, Adana, Turkiye

${ }^{4}$ Hacettepe University Faculty of Medicine, Department of Urology, Ankara, Turkiye

${ }^{5}$ Ankara University Faculty of Medicine, Department of Urology, Ankara, Turkiye

${ }^{6}$ Başkent University Faculty of Medicine, Department of Urology, Ankara, Turkiye

${ }^{7}$ Osmangazi University Faculty of Medicine, Department of Urology, Eskişehir, Turkiye

${ }^{8}$ Göztepe Training and Research Hospital, Clinic of Urology, Istanbul, Turkiye

${ }^{9}$ Marmara University Faculty of Medicine, Department of Urology, Istanbul, Turkiye

What's known on the subject? and What does the study add?

To the best of our knowledge, this is the first study that validates renal cell carcinoma 2010 tumor-node-metastasis for the Turkish population.

\begin{abstract}
Objective: The American Joint Committee on Cancer tumor-node-metastasis (TNM) classification has been updated by the $7^{\text {th }}$ edition in 2010 . The objective of the study was to evaluate cancer-specific survival (CSS) in patients with renal cell carcinoma (RCC) and assess the concordance of 2002 and novel 2010 TNM primary tumor classifications.

Materials and Methods: A retrospective analysis of RCC registries from 25 institutions of the Urooncology Association of Turkey Renal CancerStudy Group was performed. Patients with RCC had a radical or partial nephrectomy. The database consisted of 1889 patients.

Results: Median follow-up time was 25 months (interquartile range: 11.2-47.8). The 5-year CSS rate for pT1a, pT1b, pT2a, pT2b, pT3a and pT4 tumors were 97\% [95\% confidence interval (Cl): 0.93-0.99], 94\% (95\% Cl: 0.91-0.97), 88\% (95\% Cl: 0.81-0.93), 77\% (95\% Cl: 0.64-0.86) 74\% (95\% Cl: $0.65-0.81)$ and $66 \%(95 \% \mathrm{Cl}: 0.51-0.77)$, respectively according to the 2010 TNM classification ( $<<0.001)$. CSS comparisons between pT1a-pT1b $(p=0.022), p T 1 b-p T 2 a(p=0.030), p T 3 a-p T 3 b(p<0.001)$ and pT3b-pT4 $(p=0.020)$ were statistically significant. Conversely, $p$ T2a-pT2b $(p=0.070)$ and pT2b-pT3a ( $p=0.314)$ were not statistically significant. Multivariable analyses revealed the $p$ T stage in the 2010 TNM classification as an independent prognostic factor for CSS ( $p$ for trend=0.002). C-indexes for 2002 and 2010 TNM classifications were 0.8683 and 0.8706 , respectively.

Conclusion: Subdividing pT2 does not have a CSS advantage. Moving adrenal involvement to pT4 yielded a more accurate prognosis prediction. T stage and LNI are independent prognostic factors for CSS in RCC. Overall, the novel 2010 TNM classification is slightly improved over the former one. However, shown by C-index values, this improvement is not sufficient to state that 2010 TNM outperforms the 2002 TNM.
\end{abstract}

Keywords: Renal cell carcinoma, kidney cancer, 2010 tumor-node-metastasis, primary tumor classification

Correspondence: Tayyar Alp Özkan MD, University of Health Sciences, Kocaeli Derince Training and Research Hospital, Clinic of Urology, Kocaeli, Turkiye Phone: +90 2623178000 E-mail: alpozkan@gmail.com

Received: 13.02.2017 Accepted: 19.02.2017

Presented in: $1^{\text {st }}$ Urological Surgery Congress as an abstract in 2012.

Cite this article as: Özkan TA, Eskiçorapçı S, Yaycıoğlu Ö, Akdoğan B, Göğüs Ç, Dirim A, Can C, Yıldırım A, Özen H, Türkeri L, Urooncology Association of Turkey Renal Cancer-Study Group. An Independent Validation of 2010 Tumor-Node-Metastasis Classification for Renal Cell Carcinoma: A Multi-center Study by the Urooncology Association of Turkey Renal Cancer-Study Group. J Urol Surg 2017;4:53-60.

๑Copyright 2017 by the Association of Urological Surgery / Journal of Urological Surgery published by Galenos Publishing House. 
$\ddot{0} z$

Amaç: Amerikan Kanser Ortak Komitesi tümör-nod-metastaz (TNM) tümör sınıflaması 7. basım ile güncellendi. Bu çalışmada böbrek hücreli karsinom (BHK) 2002 ve 2010 TNM sınıflamaları kansere özgü sağkalım (KÖS) açısından değerlendirildi.

Gereç ve Yöntem: Üroonkoloji Derneği Böbrek Kanseri Çalışma Grubu üyesi 25 merkezin radikal veya parsiyel nefrektomi yapılmış BHK hasta kayıtları geriye dönük olarak değerlendirildi. Çalışmaya 1889 hasta dahil edildi.

Bulgular: Hastaların ortanca takip süresi 25 ay (çeyrek değerler genişliği: 11,2-47,8) idi. TNM 2010'a göre 5 yıllık KÖS pT1a'da \%97 [\%95 güven aralığı (GA): 0,93-0,99], pT1b'de \%94 (\%95 GA: 0,91-0,97), pT2a'da \%88 (\%95 GA: 0,81-0,93), pT2b'de \%77 (\%95 GA: 0,64-0,86), pT3a'da \%74 (\%95 GA: 0,65-0,81) ve pT4'te \%66 (\%95:0,51-0,77) olarak saptandı (log-rank p<0,001). pT grupları arası ikili karşılaştırma pT1a-pT1b (p=0,022), pT1b-pT2a $(p=0,030)$, pT3a-pT3b $(p<0,001)$ ve pT3b-pT4 $(p=0,020)$ arasında istatistiksel olarak anlamlı idi. Ancak pT2a-pT2b ve pT2b-pT3a $(p>0,05)$ istatistiksel olarak anlamlı değildi. Tek değişkenli ve çok değişkenli analizlerde pT evresi 2010 TNM evresi bağımsız prognostik faktör olarak saptandı ( $p$ for trend=0,002). TNM 2002 için C-indeks=0,8683 ve TNM 2010 için c-indeks=0,8706 olarak saptandı.

Sonuç: pT2'yi pT2a ve pT2b olarak ayırmak KÖS açısından avantaj sağlamamaktadır. Adrenal invazyonunu pT4'e taşımak daha doğru bir prognoz öngörüsü sağladı. BHK'de lenf nodu tutulumu ve pT evresi KÖS için bağımsız prognostik faktördür. TNM 2010 C-indeks sonuçlarına göre KÖS için TNM 2002 sınıflamasından daha üstün değildir.

Anahtar Kelimeler: Böbrek hücreli kanser, böbrek kanseri, 2010 tümör-nod-metastaz, primer tümör sınıflaması

\section{Introduction}

The tumor-node-metastasis (TNM) primary tumor staging classification is an internationally accepted and widely used tool to determine the anatomical extent of cancer spread. TNM classification system categorizes tumors on the basis of primary tumor characteristics $(T)$, the presence or absence of regional lymph node involvement (LNI) $(\mathrm{N})$, and the presence or absence of distant metastases (M) including non-regional LNIs. It is an essential part of the reports for the assessment of the prognosis of malignancies.

The major changes in renal cell carcinoma (RCC) in the 2010 American Joint Committee on Cancer TNM ( $7^{\text {th }}$ edition) with respect to 2002 version were re-classification of ipsilateral adrenal involvement from $\mathrm{pT} 3 \mathrm{a}$ to $\mathrm{pT} 4$, and renal vein involvement (RVI) from pT3b to pT3a. Also, pT2 tumors were subdivided into tumors greater than $7 \mathrm{~cm}$ and less than $10 \mathrm{~cm}$ into pT2a and tumor limited to kidney and greater than $10 \mathrm{~cm}$ into pT2b groups (1). LNI was simplified as yes or no regardless of a single or multiple LNI as in 2002 version.

The objective of the present study was to evaluate cancerspecific survival (CSS) in RCC patients operated by the surgeons member of the Urooncology Association of Turkey Renal Cancer-Study Group (UATRC-SG) and assess the concordance of 2002 and novel 2010 TNM primary tumor classifications.

\section{Materials and Methods}

A retrospective analysis of $\mathrm{RCC}$ registries from 25 member institutions of the UATRC-SG was performed. These centers contributed with their data from all patients who underwent radical or partial nephrectomy between 1987 and 2007 for kidney tumors and had no evidence of metastasis at the time of surgery. Decision, either for partial or radical nephrectomy was made on the discretion of the operating surgeon.
A total of 1889 patients had been operated and 198 of them underwent partial nephrectomy. Patients with von HippelLindau disease and synchronous bilateral tumors were not included in the database. Collected data from all centers were pooled in a single database. For the purposes of this study, the contents of the data consisted of patients' date of birth, gender, presence of systemic symptom, presentation, surgical approach, pathological size, perinephric fat invasion (PNI), RVI, adrenal invasion, invasion beyond Gerota's fascia, LNI, pathological T and $\mathrm{N}$ stage (2002 TNM), Fuhrman nuclear grade, histological tumor type, adjuvant treatment, recurrence, vital status, date of death, cause of death, and date of last follow-up parameters. The data was originally recorded with 2002 TNM classification. For the purposes of this study, patients' pT stages were re-assigned into 2010 TNM stage. Consequently, the database consisted of 1889 patients.

Five centers submitted more than 100 patients, 11 submitted 50 to 100 , and 9 submitted less than 50 patients. Overall, $45.05 \%$ $(n=851)$ of patients were submitted by 5 centers that provided data on more than 100 cases. The number of patients operated before 1997, between 1997 and 2002, and after 2002 were 82 (4.34\%), $389(20.59 \%)$ and $1418(75.07 \%)$, respectively (Table 1). Patients from all centers were included regardless of the participant center's patient volume in this study.

Apart from minor differences in clinical practice, common follow-up protocol included physical examination, serum blood urea nitrogen and creatinine determination, chest and abdominal computed tomography scanning every 6 months for 2 years and annually thereafter.

The underlying cause of death was obtained from death certificates and medical records. In the absence of any of these, telephone conversation with patients' relatives was used to determine the time and cause of death. 


\section{Statistical Analysis}

The results were expressed as means \pm standard deviation and median [interquartile range (IOR)]. All evaluated variables except for age and pathological tumor size were categorical. Patients were censored at the time of death for other reasons or last follow-up. Patients were considered as failed if they died of RCC. Survival probability was estimated using the KaplanMeier method. Log-rank test was used to compare CSS between the groups. CSS was calculated for median survival time and 5-year survival. Trend test was constructed using the log-rank test. Concordance index was used to further compare the predictive ability of the 2002 and 2010 TNM classifications (2). Univariable and multivariable analyses were performed with Cox proportional hazards regression model and 95\% confidence intervals (Cls) were calculated. All analyses were performed using STATA 12.0 statistical software package (Stata Corp, Texas, USA). Statistical significance was set at 0.05 and all tests were two-tailed.

\section{Results}

A total of 1889 patients operated for RCC were included in this study. Clinical and pathological features of these patients are summarized in Table 2. Median follow-up time was 25 months (IQR: 11.2-47.8) for the whole cohort and 25.4 months (IQR: 11.8-48.8) for the surviving patients. Of all, 151 (8\%) patients died from RCC at a median follow-up of 20.4 months (IQR: 7.1-36) and 73 (3.9\%) died from other causes. Seven hundred eighty-two patients (41.4\%) who were alive at last follow-up had fewer than 24 months of follow-up. Death due to disease

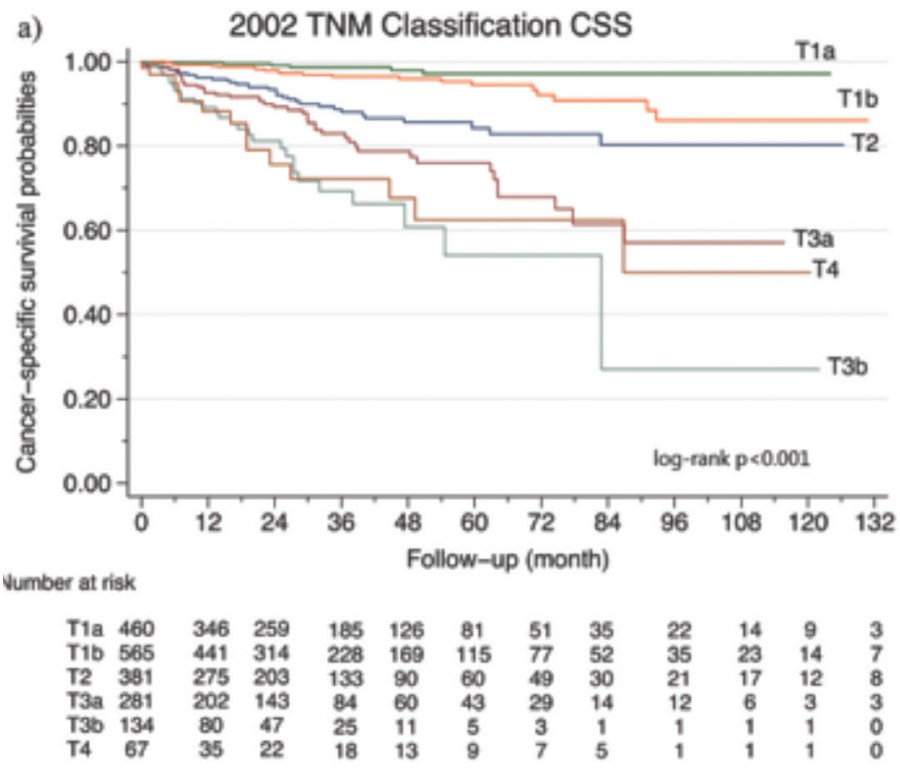

was observed in $79.5 \%$ of the patients (120/151) with in the first 2 years. A total of 311 patients (16.5\%) had been followed for more than 60 months. Recurrent disease was seen in 208 patients (13.7\%). Adjuvant treatment was given to 106 patients (9.9\%).

The 2-year CSS rates for pT1a, pT1b, pT2a, pT2b, pT3a, pT3b and pT4 tumors were 98\% (95\% Cl: 0.95-0.99), 96\% (95\% Cl: 0.93-0.98), 88\% (95\% Cl: 0.81-0.93), 81\% (95\% Cl: 0.70-0.88), 79\% (95\% Cl: 0.71-0.84), 46\% (95\% Cl: 0.23-0.67), and 68\% (95\% Cl: 0.54-0.79), respectively according to the 2010 TNM classification. The respective 5 -year CSS rates for $\mathrm{pT} 1 \mathrm{a}, \mathrm{pT} 1 \mathrm{~b}$, pT2, pT3a, pT3b and pT4 tumors were 98\% (95\% Cl: 0.94-0.99), 96\% (95\% Cl: 0.92-0.98), 89\% (95\% Cl: 0.83-0.93), 89\% (95\% Cl: $0.80-0.94) 64 \%$ (95\% Cl: $0.36-0.83)$ and $75 \%$ (95\% Cl: $0.54-$ $0.88)$, according to the 2002 TNM classification. The respective 5 -year CSS rates for pT1a, pT1b, pT2a, pT2b, pT3a and pT4 tumors were $97 \%$ (95\% Cl: 0.93-0.99), 94\% (95\% Cl: 0.91-0.97), 88\% (95\% Cl: 0.81-0.93), 77\% (95\% Cl: 0.64-0.86) 74\% (95\% $\mathrm{Cl}: 0.65-0.81)$ and $66 \%(95 \% \mathrm{Cl}: 0.51-0.77)$, according to the 2010 TNM classification (log-rank $p<0.001$, Figure 1). No CSS outcome was provided for pT3b stage group at 5 years since there was no patient followed up for more than 52 months in the group. No patient was registered for stage pT3c disease.

Pairwise CSS comparisons for consecutive T stages according to 2010 TNM classification between pT1a-pT1b $(p=0.022)$, $p T 1 b-$ pT2a $(p=0.030)$, pT3a-pT3b $(p<0.001)$ and pT3b-pT4 $(p=0.020)$ were statistically significant. However, pairwise comparisons between $\mathrm{pT} 2 \mathrm{a}-\mathrm{pT} 2 \mathrm{~b}(\mathrm{p}=0.070)$ and $\mathrm{pT} 2 \mathrm{~b}-\mathrm{pT} 3 \mathrm{a}(\mathrm{p}=0.314)$ were not statistically significant. When 1761 patients without LNI

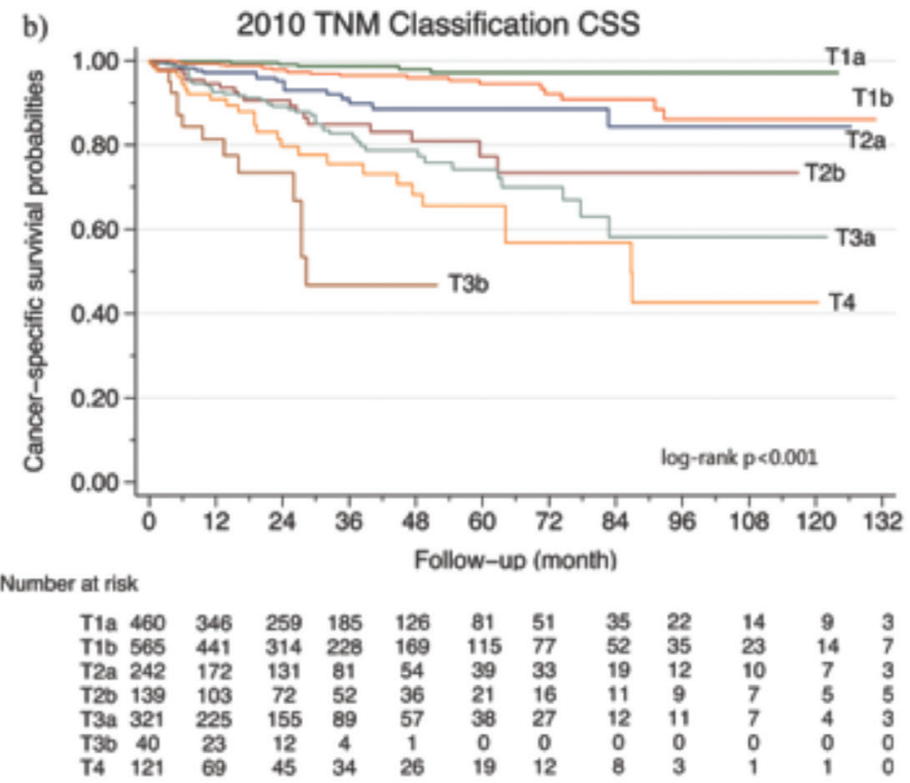

Figure 1. Cancer-specific survival probability according to 2002 (a) and 2010 (b) tumor-node-metastasis classification TNM: Tumor-node-metastasis, CSS: Cancer-specific survival 
were considered, only pairwise CSS comparison between pT1a and $\mathrm{pT} 1 \mathrm{~b}(\mathrm{p}=0.009)$ was statistically significant.

When pT3a was substratified/subdivided according to PNI and RVI, 246 cases had PNI only (76.4\%), 30 RVI only (9.3\%) and 46 patients (14.3\%) had both. Pairwise CSS comparisons of RVI vs. PNI [hazard ratio (HR): 4.35 95\% Cl: 0.59-31.8 $p=0.147$ ] and PNI vs. RVI + PNI (HR: 1.96 95\% Cl: 0.9-4.1 p=0.072), failed to disclose statistically significant difference (Figure 2). However, RVI only group had statistically significantly better CSS than RVI + PNI group (HR: 8.52 95\% Cl: 1.1-67.6 $p=0.043$ ). When lymph node-positive 38 patients were excluded, CSS differences between all subgroups were not statistically significant (data not shown).

Table 1. Number of patients' distribution among participated centers

\begin{tabular}{|c|c|c|}
\hline Participated center & $\mathbf{n}$ & $\%$ \\
\hline Ankara Training and Research Hospital & 36 & 1.91 \\
\hline Ankara Numune Training and Research Hospital & 70 & 3.71 \\
\hline Ankara University Faculty of Medicine & 392 & 20.75 \\
\hline Atatürk Training and Research Hospital & 15 & 0.79 \\
\hline Başkent University Adana Hospital & 62 & 3.28 \\
\hline Başkent University Faculty of Medicine & 116 & 6.14 \\
\hline Celal Bayar University Faculty of Medicine & 26 & 1.38 \\
\hline Çukurova University Faculty of Medicine & 34 & 1.80 \\
\hline Cumhuriyet University Faculty of Medicine & 32 & 1.69 \\
\hline Dicle University Faculty of Medicine & 25 & 1.32 \\
\hline Ege University Faculty of Medicine & 98 & 5.19 \\
\hline Erciyes University Faculty of Medicine & 93 & 4.92 \\
\hline Göztepe Training and Research Hospital & 64 & 3.39 \\
\hline Hacettepe University Faculty of Medicine & 101 & 5.35 \\
\hline $\begin{array}{l}\text { Haydarpaşa Sultan Abdülhamid Training and } \\
\text { Research Hospital }\end{array}$ & 80 & 4.24 \\
\hline $\begin{array}{l}\text { Haydarpaşa Numune Training and Research } \\
\text { Hospital }\end{array}$ & 62 & 3.28 \\
\hline İnönü University Faculty of Medicine & 34 & 1.80 \\
\hline $\begin{array}{l}\text { Kartal Training and Research Hospital, } 1^{\text {st }} \\
\text { Department of Urology }\end{array}$ & 34 & 1.80 \\
\hline $\begin{array}{l}\text { Kartal Training and Research Hospital, } 2^{\text {nd }} \\
\text { Department of Urology }\end{array}$ & 17 & 0.90 \\
\hline Kocaeli University Faculty of Medicine & 58 & 3.07 \\
\hline Marmara University Faculty of Medicine & 110 & 5.82 \\
\hline Mersin University Faculty of Medicine & 7 & 0.37 \\
\hline Ondokuz Mayıs University Faculty of Medicine & 55 & 2.91 \\
\hline Osmangazi University Faculty of Medicine & 99 & 5.24 \\
\hline Tepecik Training and Research Hospital & 132 & 6.99 \\
\hline Trakya University Faculty of Medicine & 37 & 1.96 \\
\hline Total & 1.889 & 100 \\
\hline
\end{tabular}

The pT3b category consisted of 40 patients and 20 (50\%) had infradiaphragmatic vena cava involvement (IVCI) only. Both PNI and IVCI were present in 20 patients (50\%). Patients who had $\mathrm{PNI}+\mathrm{IVCl}$ had poorer CSS compared to IVCl only patients (HR: 4.98 95\% Cl: 1.1-22.6 p=0.015). When 8 lymph node-positive patients were excluded, this statistically significant difference was lost $(p=0.089)$.

A total of 121 patients were in the pT4 category. Forty-eight patients had invasion beyond Gerota's fascia and 73 patients had ipsilateral continuous adrenal invasion. No statistically significant difference was noted in CSS between Gerota's fascia invasion and adrenal invasion subgroups (HR: $1.14 \mathrm{p}=0.75$ ). When lymph node-positive patients were excluded, analysis on a total of 41 patients also resulted in non-significant difference $(p=0.73)$.

On the univariable Cox regression analysis, age, gender, mode of presentation, type of surgery, histological tumor type, tumor size, pT stage, lymph node invasion, and Fuhrman nuclear grade all emerged as significant prognostic factors for CSS (Table 3). On the univariable analyses for 2002 and 2010 TNM pT stage, $C$-indexes were $0.7626(p<0.001)$ and $0.7694(p<0.001)$, respectively. pT stage classifications in both 2002 and 2010 TNM staging systems resulted in statistically significant CSS prediction and c-index improved in the novel 2010 TNM classification. When patients with LNI excluded from the analysis 2002 and 2010 TNM pT stage remained statistically significant $(p<0.001)$ C-indexes were 0.7463 and 0.7516 , respectively.

On the multivariable analyses, age, type of surgery, and tumor size were not independent prognostic factors and were excluded from the final model. When controlled with all other covariates (gender, presentation, histological tumor type, Fuhrman grade, pathological tumor size, $\mathrm{T}$ and $\mathrm{N}$ stage) in the multivariable analyses, the pT stage in the 2010 TNM classification was an

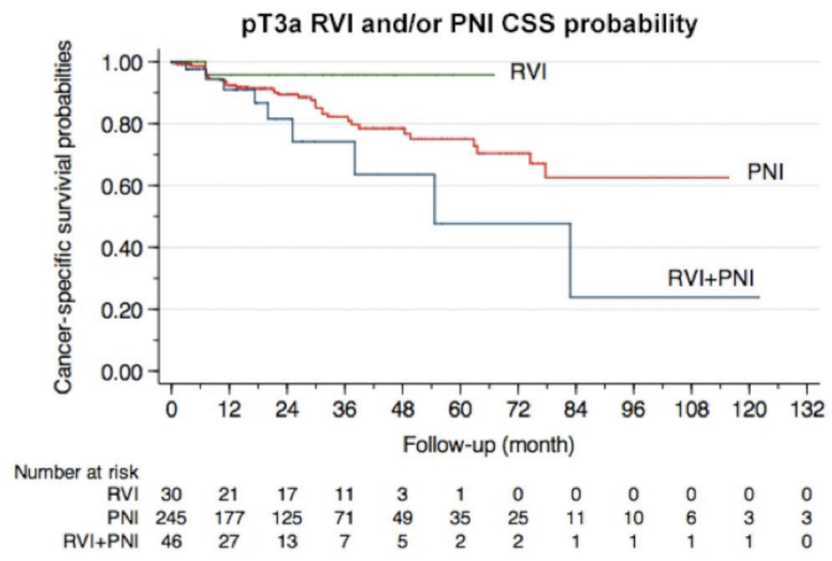

Figure 2. Cancer-specific survival probability for pT3a according to renal vein and/or perinephric involvement

RVI: Renal vein involvement, PNI: Perinephric fat invasion, CSS: Cancer-specific survival 
Table 2. Clinical and pathological characteristics of the patients $(n=1889)$

\begin{tabular}{|c|c|}
\hline Age, years, median (IOR) & $57(48-65)$ \\
\hline \multicolumn{2}{|l|}{ Gender, no (\%) } \\
\hline Male & $1178(62.4)$ \\
\hline Female & $711(37.6)$ \\
\hline \multicolumn{2}{|l|}{ Presentation, no (\%) } \\
\hline Incidental & $821(43.5)$ \\
\hline Local symptoms & $821(43.5)$ \\
\hline Systemic symptoms & $247(13.1)$ \\
\hline \multicolumn{2}{|l|}{ Type of surgery, no (\%) } \\
\hline Radical nephrectomy & $1691(89.5)$ \\
\hline Partial nephrectomy & $198(10.5)$ \\
\hline \multicolumn{2}{|l|}{ Histological tumor type ${ }^{\dagger}$, no (\%) } \\
\hline Clear cell & $1431(80.7)$ \\
\hline Papillary & $185(10.4)$ \\
\hline Chromophobe & $138(7.8)$ \\
\hline Collecting duct & $12(0.7)$ \\
\hline Unclassified & $8(0.4)$ \\
\hline \multicolumn{2}{|l|}{ Fuhrman nuclear grade ${ }^{\ddagger}$, no (\%) } \\
\hline Grade I & $212(13.2)$ \\
\hline Grade II & $883(54.9)$ \\
\hline Grade III & $409(25.4)$ \\
\hline Grade IV & $105(6.5)$ \\
\hline Pathological tumor size, mm, median (IQR) & $60(40-85)$ \\
\hline \multicolumn{2}{|l|}{ Pathological T stage (2002 TNM), no (\%) } \\
\hline T1a & $460(24.4)$ \\
\hline T1b & 565 (29.9) \\
\hline T2 & $381(20.2)$ \\
\hline Т3а & $282(14.9)$ \\
\hline T3b & $134(7.1)$ \\
\hline Т3c & 0 \\
\hline T4 & $67(3.5)$ \\
\hline \multicolumn{2}{|l|}{ Pathological T stage (2010 TNM), no (\%) } \\
\hline T1a & $460(24.4)$ \\
\hline T1b & 565 (29.9) \\
\hline T2a & $242(12.8)$ \\
\hline $\mathrm{T} 2 \mathrm{~b}$ & $139(7.4)$ \\
\hline Т3а & $322(17)$ \\
\hline T3b & $40(2.1)$ \\
\hline T3c & 0 \\
\hline T4 & $121(6.4)$ \\
\hline \multicolumn{2}{|l|}{ Pathologic N stage (2010 TNM), no (\%) } \\
\hline $\mathrm{Nx}$ & $8(0.4)$ \\
\hline No & $1761(93.2)$ \\
\hline N1 & $120(6.4)$ \\
\hline $\begin{array}{l}{ }^{+} \text {Missing in } 115 \text { patients } \\
{ }^{+} \text {Missing in } 290 \text { patients } \\
\text { IQR: Interquartile range, TNM: Tumor-node-metastasis }\end{array}$ & \\
\hline
\end{tabular}

independent prognostic factor for CSS ( $p$ for trend=0.002) (Table 3). However, when pT1a stage was used as a reference, pT1b stage was not an independent prognostic factor (HR: $1.9 \mathrm{p}=0.211)$. In the final model, $\mathrm{C}$-indexes for 2002 and 2010 TNM classifications were 0.8683 and 0.8706 , respectively. When only 1731 No patients were considered, the PT stage retained its significance as an independent prognostic factor ( $p$ for trend $=0.011$ ).

\section{Discussion}

Prediction of CSS is one of the main issues for malignant diseases. The TNM primary tumor classification system is a widely used, validated tool for this purpose (3). This classification system is a common ground for evaluating the anatomical extent of malignancies.

In the present study, analysis revealed that some of the changes made between T stages in 2010 TNM classification improved prediction of CSS for RCC.

The change in pT2 stage in 2010 TNM classification is a topic still under debate. This change was based on a single study (4). In this study, results of 544 patients were evaluated and a $10 \mathrm{~cm}$ cut-off point was assigned for the subdivision of pT2 patients into pT2a and pT2b. However, other studies did not support a $10 \mathrm{~cm}$ cut-off for pT2 group $(5,6,7,8)$. In a detailed analysis of pT2 group, Brookman-May et al. (5) reported that neither a cut-off value of $10 \mathrm{~cm}$ nor alternative cut-off values $(8,9,11,12,13 \mathrm{~cm})$ had an impact on CSS. In another study, a cut-off value of $11 \mathrm{~cm}$ was offered for the subdivision of pT2a and $b$ (9). It is argued that tumor aggressiveness features, as collecting system invasion in one study, may be more important than tumor size alone in the determination of prognosis (5). The present study also revealed no statistically significant difference in CSS between 2010 pT2a and pT2b TNM stages, similar to the other previously reported series $(5,6,7,8)$. Additionally, T2b-T3a patients had similar prognosis in the present study cohort. This may be due to the small number of patients with fewer failures in $\mathrm{T} 2 \mathrm{~b}$ group.

In 2005, Thompson et al. (10) reported that in the 2002 TNM classification, pT3a patients had unfavorable prognosis because of ipsilateral adrenal involvement when compared with pT3a patients with PNI only. In addition, prognosis in these patients with adrenal involvement was similar to that in pT4 group. Based on this data, patients with ipsilateral adrenal involvement were placed into pT4 group in the 2010 TNM classification. In the same study in pT3b group, patients with PNI died twice as likely as not PNI cases. Based on this observation concerning PNI status and level of tumor thrombus, a new classification for pT3 patients was offered (10) as follows: pT3a (RVI only), pT3b (PNI only), pT3c (PNI or IVCI), and pT3d (PNI + IVCl or VCl above 
Table 3. Univariable and multivariable Cox regression analyses of cancer-specific mortality

\begin{tabular}{|c|c|c|c|c|}
\hline \multirow[t]{2}{*}{ Variables } & \multicolumn{2}{|l|}{ Univariable } & \multicolumn{2}{|l|}{ Multivariable } \\
\hline & $\mathrm{HR}(95 \% \mathrm{Cl})$ & $\mathbf{p}$ & $\mathrm{HR}(95 \% \mathrm{Cl})$ & $\mathbf{p}$ \\
\hline \multicolumn{5}{|l|}{ Gender } \\
\hline Male & 1 reference & - & 1 reference & - \\
\hline Female & $0.56(0.39-0.81)$ & 0.002 & $0.63(0.412-0.967)$ & 0.034 \\
\hline \multicolumn{5}{|l|}{ Presentation } \\
\hline Incidental & 1 reference & - & 1 reference & - \\
\hline Local symptoms & $2.02(1.36-3.0)$ & 0.001 & $1.97(1.21-3.21)$ & 0.007 \\
\hline Systemic symptoms & $5.0(3.26-7.66)$ & 0.000 & $3.80(2.25-6.42)$ & 0.000 \\
\hline \multicolumn{5}{|l|}{ Histological tumor type } \\
\hline Clear cell & 1 reference & - & 1 reference & - \\
\hline Papillary & $0.86(0.50-1.50)$ & 0.601 & $1.11(0.62-2.02)$ & 0.721 \\
\hline Chromophobe & $0.17(0.04-0.68)$ & 0.012 & $0.49(0.12-2.05)$ & 0.334 \\
\hline Collecting duct & $8.53(3.12-23.33)$ & 0.000 & $0.73(0.20-2.71)$ & 0.642 \\
\hline Unclassified & $8.02(2.54-25.32)$ & 0.000 & $3.13(0.89-11.0)$ & 0.075 \\
\hline \multicolumn{5}{|l|}{ Fuhrman nuclear grade } \\
\hline Grade I & 1 reference & - & 1 reference & - \\
\hline Grade II & $1.75(0.68-4.48)$ & 0.242 & $1.61(0.45-3.0)$ & 0.758 \\
\hline Grade III & 7.55 (3.04-18.79) & 0.000 & $3.95(1.57-9.98)$ & 0.004 \\
\hline Grade IV & 18.35 (6.98-48.24) & 0.000 & $3.74(1.34-10.4)$ & 0.012 \\
\hline Pathological tumor size ${ }^{\dagger}, \mathrm{cm}$ & $1.01(1.01-1.02)$ & 0.000 & $1.00(0.99-1.00)$ & 0.698 \\
\hline \multicolumn{5}{|l|}{ Pathological T stage } \\
\hline T1a & 1 reference & - & 1 reference & - \\
\hline $\mathrm{T} 1 \mathrm{~b}$ & $2.88(1.17-7.10)$ & 0.022 & $1.93(0.69-5.41)$ & 0.211 \\
\hline $\mathrm{T} 2 \mathrm{a}$ & $5.80(2.28-14.70)$ & 0.000 & $3.28(1.10-9.78)$ & 0.033 \\
\hline $\mathrm{T} 2 \mathrm{~b}$ & $10.66(4.25-26.74)$ & 0.000 & $5.63(1.74-18.19)$ & 0.004 \\
\hline Т3a & $14.05(6.01-32.87)$ & 0.000 & $6.64(2.44-18.03)$ & 0.000 \\
\hline T3b & $48.52(18.32-128.50)$ & 0.000 & $14.26(4.40-46.3)$ & 0.000 \\
\hline $\mathrm{T} 3 \mathrm{c}^{\neq}$ & - & - & - & - \\
\hline $\mathrm{T} 4$ & $21.73(8.94-52.82)$ & 0.000 & $6.35(2.13-19.0)$ & 0.001 \\
\hline \multicolumn{5}{|l|}{ Pathologic N stage } \\
\hline No & 1 reference & - & 1 reference & - \\
\hline N1 & $9.16(6.39-13.12)$ & 0.000 & $3.65(2.32-5.72)$ & 0.000 \\
\hline \multicolumn{5}{|l|}{${ }^{+}$Calculated as continues variable } \\
\hline \multicolumn{5}{|l|}{ `No patients } \\
\hline HR: Hazard ratio, Cl: Confidence interval & & & & \\
\hline
\end{tabular}

diaphragm). In another study, the novel 2010 TNM classification was validated (11). In this study, pT3a patients were subdivided as (a) PNI invasion only, (b) RVI only, and (c) PNI + RVI. RVI only group had the most favorable outcome, followed by $\mathrm{PNI}$ and, RVI + PNI had the worst CSS. Furthermore, patients with $\mathrm{pT} 3 \mathrm{~b}$ disease were subdivided into $\mathrm{IVCl}$ and $\mathrm{PNI}+\mathrm{IVCl}$ subgroups, where PNI + IVCI had significantly worse CSS than IVCI alone (11). In the present study, the cohort had different characteristics unlike in the previously stated studies for 2010 pT3a group. Approximately $80 \%$ of the patients had only PNI. In the pT3b group, distribution of PNI only and PNI + IVCI were equal. Patients with $\mathrm{IVCl}$ had statistically significantly better
CSS than IVCl + PNI group. When lymph node-positive patients were excluded, these statistically significant CSS differences disappeared in both pT3a and pT3b groups. This is mainly due to the fact that overwhelming majority (72\%) of the patients with LNI also had advanced pT stages (pT3-4). The LNI was also an independent prognostic factor (Table 3). PNI with IVCl or RVI has a poor prognosis. On the other hand, PNI only and RVI only patients have similar prognostic outcomes (Figure 2). In this regard, simultaneous extension into two different anatomical sites ( $\mathrm{PNI}$ and $\mathrm{RVI}$ or IVCI) appears to trigger a rapid progression in disease. Our results confirmed that PNI + IVCI or PNI +RVI worsened the prognosis in TNM 2010 pT3a and pT3b subgroups 
$(10,11)$. In this context, relative influence of PNI on RVI and IVCI should be seriously considered in the subdivision of pT3a and pT3b groups in the new versions of the TNM classification.

CSS comparison between pT3b and pT4 was statically significant in favor of pT4. The Kaplan-Meier survival estimates showed a steep decrease in pT3b group during the initial 30-month follow-up period (Figure 1). This may be a consequence of small number of patients $(n=40)$ and some patients in pT3b group with minute vena cava wall invasion may be overlooked and classified as pT3b rather than pT3c. These results were also evident by wide Cls for both pT3b and pT4 groups. Considering the results of the other T stage groups, in adequate number of patients for both pT3b and pT4 groups, similar results may be obtained.

In the present study, we did not have any patients operated with tumor thrombus invading the vena cava above diaphragm or invading the wall of the vena cava. This is similar to the other RCC series in which patients classified in pT3c group also constitute a very small percentage ranging from $0.5 \%$ to $0.6 \%$ $(7,8,11,12)$.

\section{Study Limitations}

The present study has some important limitations. The most important limitation is its retrospective design. The results from 25 institutions lead to heterogeneity in preoperative work-up, surgical practice and post-operative follow-up. Other limitations were short follow-up period, lack of central pathological review, small number of pT3b and lack of pT3c patients. Concern about our short follow-up time can be alleviated by the fact that although follow-up time is median 25 months, 79.5\% of patients died from RCC before the $24^{\text {th }}$ months of follow-up. Renal sinus fat invasion was not included in the present study, as most of the pathology reports had not mentioned this status.

\section{Conclusion}

Both univariable and multivariable analyses revealed that the 2010 TNM classification had an independent prognostic value. When compared with the 2002 TNM classification, novel 2010 TNM classification slightly improved prognostic accuracy $(11,13)$. Ease of use, accumulated knowledge, and wide spread use of TNM primary staging systems maintain its contribution to other predictive models $(14,15)$.

The impact of recent targeted therapy agents on long-term prognosis is yet to be seen. In this regard, staging will continue to evolve in observance of the results with the use of these targeted agents.

Subdividing pT2 into pT2a and pT2b in the 2010 TNM classification does not have a CSS advantage. Moving ipsilateral adrenal involvement patients from pT3a to pT4 yielded a more accurate prognosis prediction in both pT3a and pT4 groups. T stage and LNI are independent prognostic factors for CSS in RCC.

Overall, the Turkish multi-institutional experience revealed that novel 2010 TNM classification is slightly improved over the former one. However, shown by $\mathrm{C}$-index values, this improvement is not sufficient to state that the 2010 TNM outperforms the 2002 TNM.

\section{Acknowledgements}

This research received no specific grant from any funding agency in the public, commercial, or not-for-profit sectors. However, we appreciate co-authors listed below for supporting this study.

UATRC-SG: Haluk Özen, Hacettepe University Faculty of Medicine, Department of Urology; Özdal Dillioğlugil, Kocaeli University Faculty of Medicine, Department of Urology; Taner Divrik, Tepecik Hospital, Clinic of Urology; Sertaç Yazıcı, Hacettepe University Faculty of Medicine, Department of Urology; Çağ Çal, Ege University Faculty of Medicine, Department of Urology; Abdullah Demirtaş, Erciyes University Faculty of Medicine, Department of Urology; Ferhat Ateş, Haydarpaşa Sultan Abdülhamid Training and Research Hospital, Clinic of Urology; Özgür Uğurlu, Ankara Numune Training and Research Hospital, $2^{\text {nd }}$ Clinic of Urology; Buğra İçli, Haydarpaşa Numune Training and Research Hospital, $1^{\text {st }}$ Clinic of Urology; Recep Büyükalpelli, Ondokuz Mayıs University Faculty of Medicine, Department of Urology; Mustafa Kaplan, Trakya University Faculty of Medicine, Department of Urology; Ali Ayyıldız, Ankara Training and Research Hospital, $2^{\text {nd }}$ Clinic of Urology; Ahmet Soylu, İnönü University Faculty of Medicine, Department of Urology; Gökhan Faydacı, Kartal Training and Research Hospital, $1^{\text {st }}$ Clinic of Urology; Semih Ayan, Cumhuriyet University Faculty of Medicine, Department of Urology; Murat Lekili, Celal Bayar University Faculty of Medicine, Department of Urology; Hayrettin Şahin, Dicle University Faculty of Medicine, Department of Urology; Mustafa Yücel Boz, Kartal Training and Research Hospital, $2^{\text {nd }}$ Clinic of Urology; Mustafa Aldemir, Atatürk Training and Research Hospital, Clinic of Urology; Murat Bozlu, Mersin University Faculty of Medicine, Department of Urology.

\section{Ethics}

Ethics Committee Approval: Retrospective study.

Informed Consent: Retrospective study.

Peer-review: Externally peer-reviewed.

\section{Authorship Contributions}

Surgical and Medical Practices: S.E., Ö.Y., B.A., Ç.G., A.D., C.C., A.Y., H.Ö., L.T., Concept: T.A.Ö., S.E., Ö.Y., Design: T.A.Ö., S.E., Data 
Collection or Processing: T.A.Ö., S.E., Ö.Y., B.A., C..G., A.D., C.C., A.Y., H.Ö., Urooncology Association of Turkey Renal CancerStudy Group, L.T., Analysis or Interpretation: T.A.Ö., Literature Search: T.A.Ö., Writing: T.A.Ö., S.E., Ö.Y.

Conflict of Interest: No conflict of interest was declared by the authors.

Financial Disclosure: The authors declared that this study received no financial support.

\section{References}

1. Edge SB, American Joint Committee on Cancer. AJCC cancer staging manual. 7th ed. New York, Springer, 2010, pp. 547-560.

2. Harrell FE Jr, Lee KL, Mark DB. Multivariable prognostic models: issues in developing models, evaluating assumptions and adequacy, and measuring and reducing errors. Stat Med 1996;15:361-387.

3. Edge $\mathrm{SB}$, American Joint Committee on Cancer. AJCC cancer staging manual. 7th ed. New York, Springer, 2010, pp. 541-546.

4. Frank I, Blute ML, Leibovich $\mathrm{BC}$, Cheville JC, Lohse $\mathrm{CM}$, Kwon ED, Zincke $\mathrm{H}$. pT2 classification for renal cell carcinoma. Can its accuracy be improved? J Urol 2005;173:380-384.

5. Brookman-May S, May M, Zigeuner R, Shariat SF, Scherr DS, Chromecki T, Moch H, Wild PJ, Mohamad-AI-Ali B, Cindolo L, Wieland WF, Schips L, De Cobelli O, Rocco B, Santoro L, De Nunzio C, Tubaro A, Coman I, Feciche $B$, Truss $M$, Dalpiaz 0 , Hohenfellner M, Gilfrich $C$, Wirth MP, Burger $M$, Pahernik S. Collecting system invasion and Fuhrman grade but not tumor size facilitate prognostic stratification of patients with pT2 renal cell carcinoma. J Urol 2011;186:2175-2181.

6. Waalkes $\mathrm{S}$, Becker $\mathrm{F}$, Schrader AJ, Janssen M, Wegener G, Merseburger AS, Schrader M, Hofmann R, Stockle M, Kuczyk MA. Is there a need to further subclassify pT2 renal cell cancers as implemented by the revised 7th TNM version? Eur Urol 2011;59:258-263.
7. Lee C, You D, Park J, Jeong IG, Song C, Hong JH, Ahn H, Kim CS. Validation of the 2009 TNM Classification for Renal Cell Carcinoma: Comparison with the 2002 TNM Classification by Concordance Index. Korean J Urol 2011;52:524-530.

8. Veeratterapillay $R$, Simren R, El-Sherif A, Johnson MI, Soomro N, Heer R Accuracy of the revised 2010 TNM classification in predicting the prognosis of patients treated for renal cell cancer in the north east of England. J Clin Pathol 2012;65:367-371.

9. Klatte T, Patard JJ, Goel RH, Kleid MD, Guille F, Lobel B, Abbou CC, De La Taille A, Tostain J, Cindolo L, Altieri V, Ficarra V, Artibani W, Prayer-Galetti T, Allhoff EP, Schips L, Zigeuner R, Figlin RA, Kabbinavar FF, Pantuck AJ, Belldegrun AS, Lam JS. Prognostic impact of tumor size on pT2 renal cell carcinoma: an international multicenter experience. J Urol 2007;178:35-40.

10. Thompson RH, Cheville JC, Lohse CM, Webster WS, Zincke H, Kwon ED, Frank I, Blute ML, Leibovich BC. Reclassification of patients with $\mathrm{pT} 3$ and $\mathrm{pT} 4$ renal cell carcinoma improves prognostic accuracy. Cancer 2005;104:53-60.

11. Novara G, Ficarra V, Antonelli A, Artibani W, Bertini R, Carini M, Cosciani Cunico S, Imbimbo C, Longo N, Martignoni G, Martorana G, Minervini A, Mirone V, Montorsi $F$, Schiavina R, Simeone C, Serni S, Simonato A, Siracusano S, Volpe A, Carmignani G. Validation of the 2009 TNM version in a large multi-institutional cohort of patients treated for renal cell carcinoma: are further improvements needed? Eur Urol 2010;58:588-595.

12. Ficarra V, Novara G, lafrate M, Cappellaro L, Bratti E, Zattoni F, Artibani W. Proposal for reclassification of the TNM staging system in patients with locally advanced (pT3-4) renal cell carcinoma according to the cancerrelated outcome. Eur Urol 2007;51:722-729.

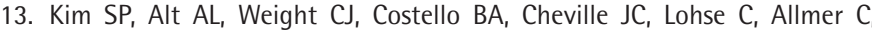
Leibovich BC. Independent validation of the 2010 American Joint Committee on Cancer TNM classification for renal cell carcinoma: results from a large, single institution cohort. J Urol 2011;185:2035-2039.

14. Kattan MW, Reuter V, Motzer RJ, Katz J, Russo P. A postoperative prognostic nomogram for renal cell carcinoma. J Urol 2001;166:63-67.

15. Frank I, Blute ML, Cheville JC, Lohse CM, Weaver AL, Zincke H. An outcome prediction model for patients with clear cell renal cell carcinoma treated with radical nephrectomy based on tumor stage, size, grade and necrosis: the SSIGN score. J Urol 2002;168:2395-2400. 